\title{
The Credential Society
}

Legacy Editions 


\section{Legacy Editions}

Edited by Howard S. Becker and Mitchell Duneier

Learning to Labor: How Working-Class Kids Get Working-Class Jobs, Paul Willis, with foreword by Stanley Aronowitz

The Levittowners: Ways of Life and Politics in a New Suburban Community, Herbert J. Gans, with foreword by Harvey Molotch

On Becoming a Rock Musician, H. Stith Bennett, with foreword by Howard S. Becker

Morals and Markets: The Development of Life Insurance in the United States, Viviana A. Rotman Zelizer, with foreword by Kieran Healy 


\section{The Credential Society}

AN HISTORICAL

SOCIOLOGY OF EDUCATION AND STRATIFICATION

\section{Randall Collins}

New preface

Forewords by Tressie McMillan Cottom and Mitchell L.Stevens

Columbia University Press / New York 
Columbia University Press

Publishers Since 1893

New York Chichester, West Sussex

cup.columbia.edu

Originally published in 1979 by Academic Press, Inc.

Copyright (C) 2019 Columbia University Press

All rights reserved

Cataloging-in-Publication Data available from the Library of Congress.

ISBN 978-0-231-19234-7 (cloth)

ISBN 978-0-23I-19235-4 (paper)

ISBN 978-0-23I-54978-3 (e-book)

Columbia University Press books are printed on permanent and durable acid-free paper.

Printed in the United States of America

Cover design: Mary Ann Smith

Cover image: Sally Anderson Archive Photos / (C) Alamy Stock Photo 
The role played in former days by the "proof of ancestry" as prerequisite for equality of birth, access to noble prebends and endowments, and wherever the nobility retained social power, for the qualifications to state offices, is nowadays taken by the patent of education. The elaboration of the diplomas from universities, business and engineering colleges and the universal clamor for the creation of further educational certifcates in all fields serve the formation of the privileged stratum in bureaus and in offices. Such certificates support their holders' claims for connubium with the notables (in business offices too they raise hopes for preferment with the boss's daughter), claims to be admitted into the circles that adhere to "codes of honor," claims for a "status-appropriate" salary instead of a wage according to performance, claims for assured advancement and old age insurance, and above all, claims to the monopolization of socially and economically advantageous positions.

If we hear from all sides demands for the introduction of regulated curricula culminating in special examinations, the reason for this is, of course, not a suddenly awakened "thirst for education," but rather the desire to limit the supply of candidates for these positions and to monopolize them for the holders of educational patents. For such monopolization, the "examination" is today the universal instrument-hence 
its irresistable advance. As the curriculum required for the acquisition of the patent of education requires considerable expenses and a long period of gestation, this striving implies a repression of talent (of the "charisma") in favor of property, for the intellectual costs of the educational patent are always low and decrease, rather than increase, with increasing volume. The old requirements of a knightly style of life, the prerequisite for capacity to bold a fief, is nowadays in Germany replaced by the necessity of participating in its surviving remnants, the dueling fraternities of the universities which grant the patents of education; in the Anglo-Saxon countries the athletic and social clubs fulfill the same function.

MAX WEBER (1968:1000; originally published 1923) 